\title{
Pay-as-You-Go Financing and Capital Outlay Volatility: Evidence from the States over Two Recent Economic Cycles
}

\author{
WEN WANG and YILIN HOU
}

\begin{abstract}
Pay-as-you-go (pay-go or cash) and pay-as-you-use (pay-use or debt) are two mechanisms to finance capital projects. While pay-go faces multiple constraints, pay-use smoothes outlays, stabilizes tax rates, and improves inter-generational equity. Thus, pay-use has dominated infrastructure financing for decades. In recent years, there has been revived academic interest in pay-go as an alternate financing mechanism; however, there is a large gap in the literature and inadequate evidence on the effects of pay-go, especially its effects on capital outlay volatility. This paper fills in the niche. Examining state experience over the two recent economic cycles, this paper finds evidence that suggests that paygo is associated with lower volatility in capital spending in the long run, but may increase short-run variability. We recommend that states couple pay-go in boom years with pay-use in lean years. In unison, the two mechanisms can reduce aggregate volatility and increase long-run stability of capital expenditures.
\end{abstract}

\section{INTRODUCTION}

The standard theory of public finance suggests that capital projects are best financed through pay-(as-you-) use means, i.e., debt, so as to spread out the payments of large amounts of one-time spending - the sheer sums of capital projects are so large that it is impossible to finance them with current revenue; thus, pay-use became necessary. As

\footnotetext{
Wen Wang is an assistant professor in the Department of Public and Social Administration, City University of Hong Kong, Tat Chee Avenue, Kowloon, Hong Kong. He holds a Ph.D. from the Maxwell School of Syracuse University. His research interests include capital budgeting and finance, education policy and finance, and fiscal disparities among local jurisdictions. He can be reached at wenwang@ cityu.edu.hk.

Yilin Hou is the Stanley W. Shelton Professor of Public Finance at the Department of Public Administration and Policy, School of Public and International Affairs, University of Georgia, 204 Baldwin Hall, Athens, GA 30602-1615. He holds a Ph.D. from the Maxwell School of Syracuse University. His research areas are fiscal-budgetary institutions, state-local taxation, and intergovernmental fiscal relations. He can be reached atyihou@uga.edu.
}

Cite as:

Wang, W., \& Hou, Y. (2009). Pay-as-You-Go Financing and Capital Outlay Volatility: Evidence from the States over Two Recent Economic Cycles. Public Budgeting \& Finance, 29(4), 90-107.

http://dx.doi.org/10.1111/j.1540-5850.2009.00944.x 
theoretical support for long-term debt, it was legitimately proposed and later became accepted that pay-use also improves intergenerational equity. ${ }^{1}$ As pay-use became the standard means of capital financing, pay-(as-you-) go financing, defined in this paper as "general fund revenues allocated for the purpose of financing capital projects,", fell to a secondary standing and has been even ignored in some cases. As a matter of fact, pay-go remains a necessary supplement to pay-use and has even been recommended by professional organizations ${ }^{3}$ and scholars as a best practice, especially when the economy is strong and/or the entity has extra resources available.

However, there has been a big gap in the public finance and budgeting literature on the working mechanisms and use of pay-go, and even less empirical research on the effects of pay-go financing on the cyclical patterns of state budgets. This study is an attempt to fill in the niche. We will first propose hypotheses regarding the impact of paygo on the stability of total capital spending; then we will empirically test the validity of our hypotheses to provide evidence on whether the use of pay-go increases or reduces the long-run volatility and short-run variability of total capital spending over the business cycle.

Capital outlays are large sums of expenditure on one-time projects; as such their adoption and approval are much more sensitive to the impact that business cycles exert on financial administration and public attitude than the recurring, current expenditure on daily operations of government finance. Capital expenditures may be drastically reduced during times of budget shortfalls ${ }^{4}$ because state governments often cut capital spending during downturns. The cut is politically easier and popular and technically realistic since the benefits of capital projects are less immediately apparent than those of maintaining current programs. Therefore, states may delay their capital spending so as to alleviate pressure on the operating budget.

On the other hand, with a developed capital/debt market and the theoretical support of compensatory fiscal policy, states may, as long as they have enough debt capacity remaining, make full use of long-term debt in a recession to maintain or even increase capital spending as a means to boost the economy. In this scenario, we can see a real complement between the two financing mechanisms: more pay-go during boom years

1. Ronald C. Fisher, "Statement before the Intergovernmental Relations and Human Resources Subcommittee of the Committee on Government Operations," in U.S. Congress, Federal and State Roles in Economic Stabilization (Washington, DC: Government Printing Office, 1984), 101-107; Richard A. Musgrave and Peggy Musgrave, Public Finance in Theory and Practice, 5th ed. (New York: McGraw-Hill, 1989); and John Mikesell, Fiscal Administration-Analysis and Application for the Public Sector, 7th ed. (Belmont, CA: Wadsworth Publishers, 2007).

2. Wen Wang, Yilin Hou, and William Duncombe, "Determinants of Pay-as-You-Go Financing of Capital Projects-Evidence from the States," Public Budgeting and Finance 27, no. 4 (2007): 18-42.

3. Government Finance Officers Association (GFOA), Recommended Budget Practices (Chicago, IL: GFOA, 1998); and National Association of State Budget Officers (NASBO), State Expenditure Report (1990-2004).

4. Leslie McGranahan, "State Budgets and the Business Cycle: Implications for the Federal Balanced Budget Amendment Debate," Economic Perspectives, 23, no. 3 (1999): 3-17. 
and more pay-use in lean years. More pay-use during recessions entails less use, and more retirement, of debt in boom years so as to reserve debt capacity. This argument for the complementary use of pay-go and pay-use was first proposed in the 1940s as a counter-cyclical fiscal policy by Alvin Hansen. ${ }^{5}$ This practice, if adopted by states, may help mitigate the impact of business cycles on capital expenditures. This is especially important during an economic recession because relatively stable capital spending can help the state economy. ${ }^{6}$

This study attempts to empirically test the effects of pay-go financing on the cyclical stability of state capital expenditures. The complementary use of pay-go and pay-use may benefit the smooth operation of state financial administration and avoid drastic fluctuations in state capital expenditures over the business cycle. While there have been some studies on the stabilization of state operating budget, ${ }^{7}$ little is known about the effect of pay-go on the stability of state capital spending. Therefore, this paper fills in the gap in the current literature. This paper is organized as follows. The next section is a brief survey of literature on pay-use and pay-go. In the third section, we offer models of capital expenditure stability over the business cycle. The fourth section describes data and methodology, with results and discussion offered in the fifth section. The last section concludes with directions for further exploration.

\section{PAY-GO VERSUS PAY-USE: A BRIEF SURVEY}

A cursory look through the financial history tells us that cash payment for all transactions was the norm for individuals, businesses (all very small in the early centuries), and government (also very small) at the onset of the commercial and market system. Later it was keenly realized by businesses (and government) that cash transaction was far

5. Yilin Hou, "Budget Stabilization Fund: Structural Features of the Enabling Legislation and Balance Levels," Public Budgeting and Finance 24, no. 3 (2004): 38-64.

6. Jun Peng, "The State Capital Funding Structure: Its Effect on the Operating Budget and Capital Spending Growth," Municipal Finance Journal 26, no. 2 (2005): 1-18.

7. See Russell Sobel and R. G. Holcombe, "The Impact of State Rainy Day Funds in Easing State Fiscal Crises during the 1990-1991 Recession," Public Budgeting and Finance 16, no. 3 (1996): 28-48; Brian Knight and Arik Levinson, "Rainy Day Funds and State Government Savings," National Tax Journal 52, no. 3 (1999): 459-472; Gary A. Wagner, "Are State Budget Stabilization Funds Only the Illusion of Savings? Evidence from Stationary Public Data," Quarterly Review of Economics and Finance 43, no. 2 (2003): 213-238; Yilin Hou, "What Stabilizes State General Fund Expenditures in Downturn Years-Budget Stabilization Fund or General Fund Unreserved Undesignated Balance?'P Public Budgeting and Finance 23, no. 3 (2003): 64-91; Yilin Hou, "Fiscal Reserves and State Own-Source Expenditure in Downturns," Public Finance Review 33, no. 1 (2005): 117-144; Gary A. Wagner and Erick M. Elder, "The Role of Budget Stabilization Funds in Smoothing Government Expenditures over the Business Cycle," Public Finance Review 33, no. 4 (2005): 439-465; and Gary A. Wagner and Russell Sobel, "State Budget Stabilization Fund Adoption: Preparing for the Next Recession or Circumventing Fiscal Constraints?" Public Choice 126, no. 1 (2006): 177-199. 
too restrictive and inadequate for (working) capital needs and investment for production expansion; the idea of "credit and debt/borrowing" was invented and put into practice. Credit and debt greatly boosted productivity, economic growth, and the market system in human history.

Founding of the American Republic saw an open debate, between Alexander Hamilton and Thomas Jefferson, concerning the consolidation of federal and state debts incurred during the Revolutionary War. Hamilton proposed consolidation to establish the credit of the United States on the financial market. Jefferson opposed Hamilton's idea, based on the belief that debt would weaken the constitutional foundation of government, in particular state autonomy, because of the resulting social and economic inequality - the wealthy bankers and speculators who bought the debt would have financial leverage on the government. In 1798, Jefferson placed a balanced budget amendment into the Constitution to eliminate the federal government's ability to borrow, which is echoed by Andrew Jackson's urge to reduce federal debt a few decades later. ${ }^{8}$

In the early 19th century, however, state and local governments borrowed heavily in the absence of regulation; defaults occurred in several states and cities. ${ }^{9}$ As part of the correction efforts, the practice of, and requirement for, "cash payment" for large items returned, under the new name of "pay-as-you-go" in the mid-19th century. ${ }^{10}$ The term crept into the finance terminology unnoticed by public finance scholars, ${ }^{11}$ yet has since occupied a permanent place in the public finance literature. ${ }^{12}$ Worth our attention is the purpose of pay-as-you-go, as stated explicitly by the New York Comptroller in 1843:

The State of New York should not be in debt. In all future operations, its agents should be required to pay as they go, and not spend the people's money until they have it in hand. ${ }^{13}$

8. Carolyn Webber \& Aaron Wildavsky, A History of Taxation and Expenditure in the Western World (New York: Simon \& Schuster, 1986); James D. Savage, Balanced Budgets and American Politics (Ithaca, NY: Cornell University Press, 1988); and Linda K. Kowalcky and Lance T. LeLoup, "Congress and the Politics of Statutory Debt Limitation," Public Administration Review 53, no. 1 (1993): 14-27.

9 Ronald C. Fisher, State and Local Public Finance, 2nd ed. (Chicago: Irwin, 1996); and D. Roderick Kiewiet and Kristin Szakaly, "Constitutional Restrictions on Borrowing: An Analysis of State Bonded Indebtedness," Journal of Law, Economics, and Organization 12, no. 1 (1996): 62-97.

10. New York State Comptroller used it in his 1843 annual report.

11. It cannot be ascertained "by whom this term was invented [or] when it was first advanced in application to the policy of financing permanent improvements from current revenues ...." See Paul Studensky, Public Borrowing (New York City: The Ford Baltimore Press, 1930), 19.

12. John Bogarde Bazuin, "A Study of the Financing of the Construction of Municipal Permanent Improvements out of Current Revenues Contrasted with the Traditional Method of Borrowed Funds and a Practical Evaluation of the Principles Evolved through an Analysis of the Pay-as-You-Go Plans of Three American Municipalities," unpublished doctoral dissertation, Michigan State College, 1941.

13. Annual Report of New York State Comptroller for 1843, p. 27 (quoted in Studensky, p. 19), emphasis added. 
As another correction effort in reaction to these defaults, balanced budget requirements (BBRs) and debt limitations were subsequently added into state constitutions and laws. $^{14}$

After the Civil War, "reconstruction" and large-scale "internal improvements" started a new round of borrowing in the states, until the Progressive Movement reinstalled the balanced budget norm as a symbol of efficiency and integrity in government. Alongside the turn toward liberal fiscal policy in the 1930 s, ${ }^{15}$ the Keynesian theory legitimized deficit spending; heavy borrowing was reignited. Even then, opponents attacked the New Deal and the deficits associated with it, establishing the foundations of debate over federal borrowing. The debate has continued till the present day. ${ }^{16}$ Occasional defaults by state and local governments also prompted the passage of state constitutional restrictions upon debt financing during the 20 th century. ${ }^{17}$ Thus, it can be concluded that during much of the U.S. history, public debt has been considered as a threat to the solvency of governments and should therefore be avoided as much as possible. Although the balanced budget norm was often violated when governments had no choice but to borrow in order to finance large capital projects and wars, it has been widely held by the general citizenry and elected officials that state and local governments should in principle balance their budgets annually.

The debate about, and the shift of practice between, the two financing mechanisms did not stop; in fact academic research went deeper, exploring the constitutional, political, economic as well as social aspects of pay-go versus pay-use. There are several advantages in using pay-go to finance capital improvement. It saves interest expenditures that can be used to expand future services or to reduce the tax rate. It also permits greater flexibility for future operations because less of the budget is committed to annual debt service payments. Pay-go financing preserves debt capacity and helps governments to achieve a more favorable credit rating that can reduce interest costs when borrowing is necessary. An argument for using pay-go to finance at least a share of capital projects is the desire to leave a legacy of capital structure to the next generation of users. The concept of patrimony coincides with the notion of pay-go and seems to make the most sense in established and stable communities. ${ }^{18}$

14. Kiewiet and Szakaly; Yilin Hou and Daniel Smith, "A Framework for Understanding State Balanced Budget Requirement Systems: Re-Examining Distinctive Features and an Operational Definition," Public Budgeting and Finance 26, no. 3 (2006): 22-45.

15. Herbert Stein, The Fiscal Revolution: Policy in Pursuit of Reality, 2nd ed. (Washington, DC: The AEI Press, 1996).

16. Kowalcky and LeLoup (1993).

17. James C. Clingermayer and B. Dan Wood, "Disentangling Patterns of State Debt Financing," The American Political Science Review 89, no. 1 (1995): 108-120.

18. George Petersen and Thomas McLoughlin, "Chapter 14: Debt Policies and Procedures," in Local Government Finance: Concepts and Practices, eds. John E. Peterson and Dennis R. Strachota (Chicago: Government Finance Officers Association, 1991), 263-273. 
Amidst the return to conservative fiscal policy in the 1970 s and $1980 \mathrm{~s}^{19}$ for smaller government and lower spending, another theory of pay-use was formulated to provide a rationale for using long-term debt to finance capital projects. ${ }^{20}$ One argument goes that if debt proceeds are invested in human infrastructure through funding education, job retraining, and health programs, then the borrowed money will benefit future taxpayers with higher incomes than they would otherwise have (if the governmental programs had not been provided). Thus, government borrowing can be easily repaid not only because taxpayers will make more money but also because people with better education will spend more purchasing goods and services from the private sector. Another positive view of government borrowing holds that debt could finance programs benefiting people who would never receive funding without government going into debt. A third positive view of debt, based on the Keynesian theory, stresses that government spending funded by debt helps stimulate the economy in a recession, which is ultimately beneficial to every individual as taxpayer and consumer. Finally, proponents of debt argue that long-term borrowing helps improve intergenerational equity. Later generations who benefit from capital projects that have a long useable life, which they will inherit, should rightly shoulder part of the accumulated debt. ${ }^{21}$

With the increasing need for debt and the convenience of obtaining it from the growing financial market, the amount of state debt increased in the 1950s to finance higher education and the improvement and replacement of roads and bridges. ${ }^{22}$ The tax revolts in the late 1970s and early 1980s restricted state/local access to guaranteed debt; then nonguaranteed debt (revenue bonds) boomed. During economic downturns of the 1980s, many states resorted to issuing debt when they were faced with declining revenues but increased program responsibilities. Therefore, states have become more reliant on long-term debt, and also shifted from reliance on general-obligation debt to nonguaranteed debt as a means to circumvent the restrictive limits on general obligation debt. ${ }^{23}$ In more recent years, the indebtedness of states has nearly reached record levels. ${ }^{24} \mathrm{Ac}-$ cording to the U.S. Census Bureau's Government Finance Statistics, state government borrowing totaled over $\$ 483$ billion and averaged $\$ 9.6$ billion per state in 1998 . The debt burden, measured as a percentage of state personal income, averaged 8.15 percent. ${ }^{25}$ By 2006 , total state debt had further increased to $\$ 871$ billion.

19. Stein (1996).

20. James M. Buchanan and Richard E. Wagner, Democracy in Deficit-The Political Legacy of Lord Keynes (New York: Academic Press, 1977).

21. Jack Rabin, "Public Debt: A Symposium,” Public Administration Review 53, no. 1 (1993): 31-49.

22. James L. Regens and Thomas P. Lauth, "Buy Now Pay Later: Trends in State Indebtedness 19501989," Public Administration Review 52, no. 2 (1992): 157-161.

23. Regens and Lauth; Roy Bahl and William Duncombe, "State and Local Debt Burdens in the 1980s: A Study in Contrast," Public Administration Review 53, no. 1 (1993): 31-49.

24. Mark D. Robbins and Casey Dungan, "Debt Diligence: How States Manage the Borrowing Function," Public Budgeting and Finance 21, no. 2 (2001): 88-105.

25. Robbins and Dungan (2001). 


\section{Business Cycles and the Volatility of State Capital Expenditures}

So far there has been very little literature, let alone empirical evidence, on the volatility of state government capital outlay over the business cycle; the effects of using pay-go versus pay-use financing are an area that has drawn almost no scholarly attention. A few studies we have found barely related to our topic are reviewed as below.

States can decrease their general fund expenditures during economic downturns by, among other measures, drastically reducing capital expenditure, which helps them to achieve budget balance. Cuts in capital spending may be politically more acceptable than cuts in other areas because capital spending presents immediate costs but only longer term benefits. However, "states' ability to alleviate general budget pressures is limited by the portion of capital spending that is being financed by current revenues." Further cuts may not be necessary since debts can be used to finance capital projects. ${ }^{26}$

Own-source revenues of state government are expected to be positively correlated with the business cycle since most of them rely on income elastic taxes such as personal and corporate income taxes and sales taxes. Empirical evidence also indicates that state revenues are procyclical. ${ }^{27} \mathrm{~A}$ previous study shows that federal grants appear to provide some insurance against state-specific downturns, controlling for U.S.-wide effects with the inclusion of time-fixed effects. ${ }^{28}$ However, some scholars argue that counter-cyclical flows of federal grants to the states are not compatible with the central government's incentives. Because tax increases and expenditure cuts are costly in political terms, central governments will face incentives to shift the costs of adjustment to subnational officials. The central government may borrow to smooth expenditures or even use "unfunded mandates" to shift their responsibilities to the states. Therefore, federal grants to the states are mostly expected to be procyclical. ${ }^{29}$

Given the procyclical properties of state own-source revenues and federal grants, the option left for the states is to use borrowing to smooth expenditures in downturn years. Empirical studies suggest that fiscal institutions such as BBRs and debt limitations may have an impact on state fiscal decisions. If these fiscal rules are effective, they may prevent state governments from using debt issuance to smooth expenditures. ${ }^{30}$

\section{MODELING CYCLICAL STABILITY OF CAPITAL OUTLAY}

Capital outlay as big items expenditure is more sensitive to the economic and revenue boom-bust cycle than current expenditure, whereas one important function of govern-

26. See McGranahan (1999), 12.

27. Erik Wibbels and Jonathan Rodden, "Fiscal Decentralization and the Business Cycle: An Empirical Study of Eight Federations," Working Paper, 2005.

28. Bent E. Sorensen and Oved Yosha, "Is State Fiscal Policy Asymmetric over the Business Cycle?" Economic Review, Third Quarter, Federal Reserve Bank of Kansas City, 2001.

29. Wibbels and Rodden (2005).

30. Ibid. 
ment is to maintain fiscal stability through policy design and implementation; thus, it is important to investigate whether prevalent capital financing mechanisms would promote, and by how much, the stability of capital spending over the business cycle. The ideal policy design would be such that the annual capital outlay is smooth with little fluctuation despite the ups and downs of the economy and the government revenue stream; that is, the flow of capital spending is "ideally" neutral to the business cycle. However, this best, theoretical scenario is possible only on paper, with the purely counter-cyclical fiscal policy as originally proposed by Hansen. ${ }^{31}$ In boom years, tax rates go high or remain stable; surplus revenue finances capital outlay in the pay-go fashion, while debt is retired or issued less, reserving the borrowing capacity for the downturn. In bust years, tax rates will be reduced while borrowing increased to provide economic stimulus; capital outlay will be financed with the pay-use mechanism. By this design, the capital stream would remain smooth, symmetrical over the expansion as well as contraction phases of the cycle.

The real-world poses various restraints on the best policy design; two restrictions are eminent. First, boom-year tax hikes are next to impossible with mounting electoral pressure for tax reductions; thus, budget surpluses will be far from adequate to cover capital outlay and debt will be necessary to maintain the capital stream required by infrastructure needs. Second, the issuance of long-term debts, with a flat debt service structure, does not consider the business cycle effect on government revenue. Whether the revenue stream is up or down, a prearranged equal amount has to be budgeted each year as debt service. In this scenario, the boom-year capital outlay consists of partly paygo and partly debt; the bust-year capital spending carries more debt but little or no paygo. The policy thereby becomes asymmetrical over the business cycle.

Besides, the practice of capital financing in the states also varies with their different tradition. For example, a fiscally liberal state may opt to use only a little pay-go mingled with debt in a boom and then issue more debt in lean years for infrastructure financing. In contrast, a fiscally conservative state may choose to go all out for pay-go in a boom, and then uses little debt and forgoes pay-go in a lean year. A previous study finds a strong correlation between a state's propensity to borrow and its ideology, with the more liberal states more likely to rely on debt to fund their capital projects and less likely to use general fund and other state funds. ${ }^{32}$

The practice of capital financing is further complicated with changing composition of the major funding sources. State capital financing mainly comes from four sources: (a) long-term debt, or borrowing; (b) other state funds, or dedicated revenues; (c) federal grants; and (d) the general fund. ${ }^{33}$ Long-term debt is either in the form of General Obligations bonds or revenue bonds that usually come with an annually flat debt service schedule. Dedicated revenues include state gasoline taxes, tolls or fees from bridges, or

31. Alvin H. Hansen, Fiscal Policy and Business Cycles (New York: Norton, 1941), 116, 261.

32. Jun Peng (2005).

33. See the State Expenditure Report series by the National Association of State Budget Officers. 
other facilities. As dedicated funds, they are usually reserved or designated for capital use only, with no regard to cyclical fluctuations of state revenue. The largest federal grant is for highway construction, and is financed by the federal tax on gasoline. As discussed in the literature review section, federal grants are usually procyclical, in a way similar to the general fund, subject to the business cycle impact at the federal and state levels. In sum, the asymmetry of capital financing policy, different fiscal tradition of each state, and varying composition of the funding sources are the three major factors that contribute to the cyclicality of state capital outlay. Our modeling is to be based on this analysis.

We first hypothesize, about an average state's long-run volatility for capital outlay, that the use of pay-go may help reduce the volatility or maintain the stability of capital expenditures in the long run. More use of surpluses (pay-go) in boom years and less in downturn years may contribute toward a smooth stream of capital investment. Debt (pay-use), in contrast, may increase the long-run volatility because of the asymmetrical distribution of its use over the cycle. Its impact on the stability of state capital outlays depends on how effective fiscal rules are in restricting states' debt issuance.

Long-run volatility and short-run cyclical variability are distinct concepts and capture different attributes of capital spending over the business cycle. Our second hypothesis is to test the effects of pay-go financing on the short-run cyclical variability of capital spending over the bust-boom of the economy and decline and rise of state revenue collections. We hypothesize that the asymmetric distribution of pay-go and pay-use will pose opposite signs from the long run: in the short run, pay-go financing may increase the cyclical variability of capital expenditures and pay-use may decrease it. Dedicated state funds may increase volatility in both the long run and the short run because they have been legally reserved or administratively designated for capital financing regardless of the economic cycle. Federal grants, being procyclical, will also be raising the volatility of capital outlay for both the long and the short run.

A review of literature indicates that political factors and fiscal rules matter in states' response to fiscal shocks and other fiscal outcomes. ${ }^{34}$ Besides examining the effects of the major financing mechanisms on the stability of state capital outlays, we also include relevant variables of state politics and fiscal institutions so as to empirically test their impact.

Based on the literature review and analysis above, we develop two empirical models of long-run and short-run state capital outlay stability over the business cycle. The general structure of the two models is shown below, with long-run capital outlay volatility (LGap) or short-run variability (SGap) as the dependent variables, respectively:

$L G a p$ or $S G a p=f$ (pay-go, other state funds, federal funds, debt, socioeconomics, demographics, politics, and fiscal institutions)

34. James M. Poterba, "Do Budget Rules Work?" in Fiscal Policy: Lessons from Economic Research, ed. Alan J. Auerbach (Cambridge, MA: MIT Press, 1997), 53-86. 


\section{DATA AND METHODOLOGY}

\section{Dependent Variables}

We construct two dependent variables to capture the long-run volatility and short-run cyclical variability of state capital expenditures, respectively. The long-run dependent variable is the absolute value of the deviation from the long-term trend of state capital outlay. ${ }^{35}$ We first use the ordinary least squares (OLS) estimator to regress capital spending against the time trend (year), assuming random distribution of expenditure data around the trend line. The model used for this regression is represented as

$$
\operatorname{Exp}_{i t}^{*}=\alpha_{i}+\beta_{i} T_{t}
$$

where $\operatorname{Exp}_{i t}^{*}$ is the predicted value of capital expenditure for state $i$ in year $t ; \alpha_{i}$ is the constant for state $i ; \beta_{i}$ is the linear trend parameter for state $i$; and $T_{t}$ is the value of the year in year $t$.

Deviations of actual capital expenditures from the trends are calculated by subtracting the trends $\left(E x p^{*}\right)$ from the actual expenditures $(E x p)$. The deviations are expressed as a percentage after being divided by the trends. Then the long-run dependent variable is constructed as the absolute value of this percentage:

$$
\operatorname{LGap}_{i t}=\left|\left(\operatorname{Exp}_{i t}-\operatorname{Exp}_{i t}^{*}\right) / \operatorname{Exp}_{i t}^{*}\right|
$$

We use the change in state capital expenditures from the immediate past year to capture its short-run variability. Thus, the short-run dependent variable is constructed as the absolute value of the first difference of capital expenditures:

$$
\operatorname{SGap}_{i, t}=\left|\operatorname{Exp}_{i, t}-\operatorname{Exp}_{i, t-1}\right|
$$

Data of pay-go spending are from NASBO's State Expenditure Report series, which is the best available source for state capital spending over the 1989-2004 period. The data are from actual figures of total state capital expenditures by source: the general fund, federal fund, other state funds and bonds. When two consecutive reports present different actual spending figures, we take the figure from the following year's report. For example, if the 1999 and 2000 reports both have a figure for actual spending in 1999 and the two are different, the figure from the 2000 report is used because the latter report has had some revision and thereby corrected possible errors in the former report. Alaska is an obvious outlier in capital spending with its mean level of pay-go spending way above that of all other states; it is excluded from the analysis, as is true with most state studies. Wisconsin is also excluded from the analysis: Although its exclusion is a bit out of the convention of state studies, the fact that its capital expenditure data are not available in this series warrants the exclusion.

35. The long-term trend of state capital expenditures is constructed based on data over the period of 1989-2004. Ideally we would like to use data from a much longer period of time to estimate the long-term trend of state capital spending, but longer-span time-series data are not available for this analysis. 


\section{Control Variables}

Socioeconomic variables include per capita income, poverty and unemployment rates, and state highway mileage per thousand population. Data for income are from the Bureau of Economic Analysis (BEA); poverty and unemployment rates and state highway mileage are from the Census Bureau. Demographic variables include population density, population growth, percent of seniors in the population, and percent of out-migration, all from the Census Bureau (the out-migration data are available only since 1989). ${ }^{36}$ Political variables include gubernatorial election cycle, the majority of the Senate being Democrat, the majority of the House being Democrat, and divided government, ${ }^{37}$ all from the Book of the States series. All financial figures are adjusted by the price index for state and local government consumption expenditures provided by the U.S. BEA. Fiscal institutions include BBRs and tax and expenditure limitations (TELs). ${ }^{38} \mathrm{BBR}$ is a matrix of four dummies: (1) the governor must submit a balanced budget; (2) the legislature must pass a balanced budget; (3) the governor must sign a balanced budget; and (4) the state may carry deficits into the next budget cycle. The BBRs data are also from the Book of the States series. TEL is a matrix of two indicator variables for revenue limitations and expenditure limitations. The two variables are constructed based on Mullins and Wallin's comprehensive study of this institution. ${ }^{39}$ Table 1 offers definitions and data sources of the variables used; Table 2 provides summary statistics of the variables.

\section{Estimation Methodology}

In estimating panel models, we face two empirical challenges. First, the model may suffer from autocorrelation of the error terms due to the time-series nature of the data. In the presence of serial correlation, the OLS is no longer a best linear unbiased estimator

36. Those socioeconomic and demographic variables are expected to reveal voter preferences for capital financing mechanisms. For example, with a higher share of older residents or mobile population, voters may be less likely to support pay-go finance of capital expenditures. Thus these variables could have a significant impact on the stability of state capital expenditures. See Wang et al. (2007).

37. Nebraska is coded 0 for divided government, since it has a nonpartisan unicameral legislature. The exclusion of Nebraska does not significantly affect the empirical results, and so it is included in the sample for the analysis.

38. Budgetary institutions are potentially endogenous to past and current fiscal outcomes and to voter tastes for fiscal restraints. However, there are at least two arguments in defense of the exogeneity of budgetary institutions. First, when the institutions are relatively stable and costly to change, and then they can be considered predetermined explanatory variables. Many of the constitutional limits on state deficits were enacted in the 19th century. The more difficult it is to change these limits, the more valuable the variation across states is in reflecting the effects of these institutions on budgetary outcomes. Second, some previous studies controlled for some measure of state voter preferences, and still found significant effects of these institutions. See James M. Poterba, "State Responses to Fiscal Crises: The Effects of Budgetary Institutions and Politics," Journal of Political Economy 102, no. 4 (1994): 799-821.

39. See Daniel R. Mullins and Bruce A. Wallin, "Tax and Expenditure Limitations: Introduction and Overview," Public Budgeting and Finance 24, no. 4 (2004): 2-15. 
TABLE 1

Variable Specifications and Data Sources

\begin{tabular}{|c|c|}
\hline Variable & Specification (data source) \\
\hline Pay-go & State per capita capital spending from General Fund (NASBO) \\
\hline Other state funds & $\begin{array}{l}\text { State per capita capital spending from other state funds } \\
\text { (NASBO) }\end{array}$ \\
\hline Bonds & State per capita capital spending from bonds (NASBO) \\
\hline Federal fund & State per capita capital spending from federal fund (NASBO) \\
\hline Per capita real income & Per capita income, in thousands (BEA) \\
\hline Poverty rate & Percentage of population in poverty (Census) \\
\hline Unemployment rate & Percentage of population unemployed (Census) \\
\hline Highway mileage & State highway mileage per 1,000 population (Census) \\
\hline Population growth & Percentage of population growth (Census) \\
\hline Population density & Population per square mile (Census) \\
\hline $\begin{array}{l}\text { Percentage of } \\
\text { population over } 65\end{array}$ & Percentage of population aged 65 and above (Census) \\
\hline $\begin{array}{l}\text { Percentage of out- } \\
\text { migration }\end{array}$ & Percentage of out-migration in the population (Census) \\
\hline $\begin{array}{l}\text { Gubernatorial election } \\
\text { cycle }\end{array}$ & 1 for governor's election year, 0 otherwise (Book of the States) \\
\hline $\begin{array}{l}\text { Senate Democrat } \\
\text { majority }\end{array}$ & 1 for Senate Democrat majority, 0 otherwise (Book of the States) \\
\hline $\begin{array}{l}\text { House Democrat } \\
\text { majority }\end{array}$ & 1 for House Democrat majority, 0 otherwise (Book of the States) \\
\hline Divided government & $\begin{array}{l}1 \text { if governor and majority of both chambers of the legislature } \\
\text { being different parties, } 0 \text { otherwise (Book of the States) }\end{array}$ \\
\hline $\begin{array}{l}\text { Submit a balanced } \\
\text { budget }\end{array}$ & 1 for submit a balanced budget, 0 otherwise (Book of the States) \\
\hline Pass a balanced budget & $\begin{array}{l}1 \text { for submit a pass a balanced budget, } 0 \text { otherwise (Book of the } \\
\text { States) }\end{array}$ \\
\hline Sign a balanced budget & $\begin{array}{l}1 \text { for submit a sign a balanced budget, } 0 \text { otherwise (Book of the } \\
\text { States) }\end{array}$ \\
\hline No deficit carryover & 1 for no deficit carry over, 0 otherwise (Book of the States) \\
\hline Revenue limit & 1 for revenue limit, 0 otherwise (Mullins and Wallin, 2004) \\
\hline Expenditure limit & 1 for expenditure limit, 0 otherwise (Mullins and Wallin, 2004) \\
\hline
\end{tabular}

Note: Financial variables (in per capita terms) are adjusted by the price index for state and local government consumption expenditures provided by the Bureau of Economic Analysis.

(Blue), and the usual OLS standard errors and hypothesis test statistics are not valid. ${ }^{40}$ The results of a test for autocorrelation in panel data suggest that first-order autocor-

40. Jeffrey M. Wooldridge, Introductory Econometrics: A Modern Approach, 2nd ed. (Cincinnati, OH: South-Western College Publishing, 2003). 
TABLE 2

Descriptive Statistics (1989-2004)

\begin{tabular}{|c|c|c|c|c|}
\hline Variable & Mean & $\begin{array}{l}\text { Standard } \\
\text { deviation }\end{array}$ & Minimum & Maximum \\
\hline Long-run volatility of capital outlay & 24.00 & 42.51 & 0.00 & 808.38 \\
\hline $\begin{array}{l}\text { Short-run variability of capital outlay (absolute } \\
\text { value of deviation from the trend in percentage) }\end{array}$ & 51.63 & 137.22 & 0.13 & $3,193.08$ \\
\hline Pay-go & 20.64 & 75.83 & 0.00 & $1,348.87$ \\
\hline Other state funds & 100.72 & 120.07 & -28.07 & $1,624.11$ \\
\hline Bonds & 71.73 & 100.70 & 0.00 & 913.73 \\
\hline Federal fund & 78.17 & 80.57 & 0.00 & 944.21 \\
\hline Per capita real income $(, 000)$ & 26.15 & 4.23 & 16.90 & 41.72 \\
\hline Unemployment rate & 5.22 & 1.41 & 2.20 & 11.40 \\
\hline Poverty rate & 12.63 & 3.70 & 2.90 & 26.40 \\
\hline Highway mileage & 25.66 & 26.60 & 3.42 & 137.09 \\
\hline Population growth & 1.06 & 2.19 & -49.77 & 11.55 \\
\hline Population density & 179.79 & 243.96 & 4.67 & $1,170.98$ \\
\hline Percentage of population over 65 & 12.74 & 1.70 & 8.53 & 18.55 \\
\hline Percentage of out-migration & 3.57 & 1.00 & 1.83 & 8.00 \\
\hline Gubernatorial election cycle & 0.27 & 0.44 & 0.00 & 1.00 \\
\hline Senate Democrat majority & 0.53 & 0.50 & 0.00 & 1.00 \\
\hline House Democrat majority & 0.58 & 0.49 & 0.00 & 1.00 \\
\hline Divided government & 0.46 & 0.50 & 0.00 & 1.00 \\
\hline Submit a balanced budget & 0.87 & 0.33 & 0.00 & 1.00 \\
\hline Pass a balanced budget & 0.76 & 0.42 & 0.00 & 1.00 \\
\hline Sign a balanced budget & 0.63 & 0.48 & 0.00 & 1.00 \\
\hline No deficit carryover & 0.17 & 0.38 & 0.00 & 1.00 \\
\hline Revenue limit & 0.32 & 0.47 & 0.00 & 1.00 \\
\hline Expenditure limit & 0.45 & 0.50 & 0.00 & 1.00 \\
\hline
\end{tabular}

Note: Financial variables (in per capita terms) are adjusted by the price index for state and local government consumption expenditures provided by the Bureau of Economic Analysis.

relation (AR1) is present in the models. ${ }^{41} \mathrm{We}$ use robust estimation; results show that first-order autocorrelation is corrected and the statistics are robust. The second challenge, despite our efforts to develop measures for the important variables in the capital expenditures volatility model, is omitted variables bias. We add in the models state-fixed effects to control for time-invariant unobservable factors and year-fixed effects to control for nationwide unobservable changes. These may help reduce the bias to a certain extent. The two empirical models for long-run volatility and short-run variability of state capital

41. The F statistics are 11.164 and 4.807 for the models with the two dependent variables, respectively; the null of no first-order autocorrelation is rejected by the test. 
expenditures can be represented as below:

$$
\begin{aligned}
\operatorname{LGap}_{i t} & =\alpha_{i}+\gamma_{t}+\beta^{\prime} x_{i t}+\varepsilon_{i t} \\
\operatorname{SGap}_{i t} & =\alpha_{i}+\gamma_{t}+\beta^{\prime} x_{i t}+\varepsilon_{i t}
\end{aligned}
$$

where $\alpha_{i}$ represents the state-fixed effects, and $\gamma_{t}$ the year-fixed effects.

\section{EMPIRICAL RESULTS AND DISCUSSION}

Table 3 reports the regression results of the effect of pay-go spending on the long-run volatility of capital expenditures. Model 1 includes the four sources of capital outlay and controls for socioeconomic variables; model 2 adds in state politics and fiscal institutions. Results from the two model specifications are consistent; the signs and magnitudes of the coefficients are not sensitive to changes in the specification, indicating that the empirical results are in general reliable. The coefficient on the pay-go variable is statistically significant at the 10 percent level. Its negative sign confirms our hypothesis that the use of pay-go financing may help reduce the long-run volatility of capital spending. Each dollar of pay-go can reduce the long-run volatility by 4.4 percent. Given that the mean value of the long-run volatility is 24 percent and the 48 -state average per capita pay-go is about $\$ 20$, this magnitude of the pay-go effect is remarkable. The coefficients on "other state funds," "bonds," and "federal fund" are all positive and statistically significant at the 1 percent level, suggesting that the use of these capital financing sources are associated with higher volatility of capital outlays in the long run. Further, these three coefficients are all larger than that of pay-go, by a margin from 14 percent (other state funds) to 77 percent (federal fund) to 107 percent (debt). Considering that their mean values are 2.5-5 times higher than that of pay-go, these funding sources push up capital spending as a trend and their effects can overwhelm that of pay-go. Against this possible scenario, the "cooling" effect of pay-go to "pull down" the up-rising trend may become much more valuable. No doubt, the real world is much more complicated than these few models can reveal, and further exploration are warranted.

The socioeconomic variables are not statistically significant except highway mileage. The negative coefficient of the variable indicates that states with higher highway mileage are likely to experience less long-run volatility of capital expenditures. Model 2 is more fully specified with the inclusion of state political and budgetary institutions to see whether these variables affect the long-run volatility of capital expenditures. Although none of them bears a statistically significant effect on the dependent variable, this full specification as a sensitivity test does not generate any flip of signs or drastic fluctuations in the magnitudes of the coefficients on the key variables of the four major capital financing sources.

Table 4 reports estimation results of the impact of pay-go on the short-run cyclical variability of capital expenditures, our second hypothesis. Here we focus on the sign and magnitude of the pay-go variable. The two models are specified in the same fashion as with the two long-run volatility models in Table 3 . The coefficient on the pay-go variable is positive 
TABLE 3

Effects on Long-Run Capital Expenditure Volatility (48 States, 1989-2004)

(Dependent variable $=$ absolute value of deviation from the trend in percentage)

\begin{tabular}{|c|c|c|c|c|}
\hline \multirow[b]{2}{*}{ Variable } & \multicolumn{2}{|c|}{ Model 1} & \multicolumn{2}{|c|}{ Model 2} \\
\hline & Coefficient & $t$-statistics & Coefficient & $t$-statistics \\
\hline Pay-go & -0.044 & $(-1.67)^{*}$ & -0.043 & $(-1.63)^{*}$ \\
\hline Other state funds & 0.051 & $(2.42)^{* *}$ & 0.053 & $(2.5)^{* * * *}$ \\
\hline Bonds & 0.091 & $(4.72)^{* * *}$ & 0.090 & $(4.67)^{* * *}$ \\
\hline Federal fund & 0.078 & $(2.75)^{* * *}$ & 0.078 & $(2.71)^{* * *}$ \\
\hline Per capita real income $(, 000)$ & -0.079 & -0.04 & -0.381 & $(-0.21)$ \\
\hline Unemployment rate & 1.469 & 0.89 & 1.567 & 0.94 \\
\hline Poverty rate & -0.108 & -0.18 & -0.083 & -0.14 \\
\hline Highway mileage & -2.519 & $(-3.5)^{* * *}$ & -2.359 & $(-3.23)^{* * *}$ \\
\hline Population growth & 0.094 & 0.24 & 0.091 & 0.23 \\
\hline Population density & 0.103 & 0.7 & 0.128 & 0.87 \\
\hline Percentage of population over 65 & 1.349 & 0.31 & 1.859 & 0.43 \\
\hline Percentage of out-migration & -0.782 & -0.12 & -0.442 & -0.07 \\
\hline Gubernatorial election cycle & & & 1.984 & 0.96 \\
\hline Senate Democrat majority & & & -5.922 & -1.22 \\
\hline House Democrat majority & & & -0.496 & -0.12 \\
\hline Divided government & & & -2.230 & -0.8 \\
\hline Submit a balanced budget & & & -2.664 & -0.35 \\
\hline Pass a balanced budget & & & -2.830 & -0.36 \\
\hline Sign a balanced budget & & & 0.294 & 0.05 \\
\hline No deficit carryover & & & -1.387 & -0.33 \\
\hline Revenue limit & & & -4.421 & -0.44 \\
\hline Expenditure limit & & & 10.969 & 1.09 \\
\hline Constant & 26.818 & 1.65 & 22.603 & 1.38 \\
\hline$R^{2}$ & 0.13 & & 0.13 & \\
\hline No. of observations & \multicolumn{2}{|c|}{648} & \multicolumn{2}{|c|}{648} \\
\hline
\end{tabular}

Notes: Statistical significance levels are as follows: ${ }^{*} 0.10,{ }^{* *} 0.05$, and ${ }^{* * *} 0.01$.

Alaska is excluded as an extreme outlier and Wisconsin excluded due to missing observations.

Financial variables (in per capita terms) are adjusted using the BEA price index for state and local government expenditures.

Coefficients for state and year dummies are available on request from authors, but are not included in the table.

and significant at the 1 percent level in both models, consistent and robust, not sensitive to changes in model specification. The results indicate that the use of pay-go financing tends to increase the cyclical variability of capital expenditures in the short run-this cyclical fluctuation comes with strong revenue streams in boom years and goes away with a sour economy. Each dollar of pay-go adds to the cyclical fluctuation by $\$ 1.62$, about 3 percentage points (coefficient 1.62 divided by 51.63, the mean of the dependent variable). 
TABLE 4

Effects on Short-Run Capital Expenditure Variability (48 States, 1989-2004) (Dependent variable $=$ absolute value of first difference in real per capita dollar values)

\begin{tabular}{|c|c|c|c|c|}
\hline \multirow[b]{2}{*}{ Variable } & \multicolumn{2}{|c|}{ Model 3} & \multicolumn{2}{|c|}{ Model 4} \\
\hline & Coefficient & $t$-statistics & Coefficient & $t$-statistics \\
\hline Pay-go & 1.616 & $(20.16)^{* * *}$ & 1.620 & $(20.04)^{* * *}$ \\
\hline Other state funds & 0.325 & $(4.83)^{* * *}$ & 0.318 & $(4.68)^{* * *}$ \\
\hline Bonds & -0.171 & $(-3.19)^{* * *}$ & -0.177 & $(-3.28)^{* * *}$ \\
\hline Federal fund & 0.309 & $(3.73)^{* * *}$ & 0.319 & $(3.79)^{* * *}$ \\
\hline Per capita real income $(, 000)$ & 14.069 & $(1.73)^{*}$ & 12.920 & 1.58 \\
\hline Unemployment rate & 10.757 & $(2.13)^{* *}$ & 11.316 & $(2.21)^{* *}$ \\
\hline Poverty rate & 1.855 & 1.18 & 2.086 & 1.31 \\
\hline Highway mileage & 3.300 & 1.01 & 3.032 & 0.92 \\
\hline Population growth & -0.944 & -0.79 & -0.909 & -0.75 \\
\hline Population density & 0.102 & 0.12 & 0.057 & 0.07 \\
\hline Percentage of population over 65 & 19.234 & 0.45 & 23.174 & 0.54 \\
\hline Percentage of out-migration & 66.240 & $(3.05)^{* *}$ & 64.025 & $(2.93)^{* * *}$ \\
\hline Gubernatorial election cycle & & & 0.940 & 0.11 \\
\hline Senate Democrat majority & & & 0.755 & 0.06 \\
\hline House Democrat majority & & & -4.288 & -0.36 \\
\hline Divided government & & & 0.529 & 0.07 \\
\hline Submit a balanced budget & & & 21.404 & 1.09 \\
\hline Pass a balanced budget & & & 6.185 & 0.27 \\
\hline Sign a balanced budget & & & -7.738 & -0.52 \\
\hline No deficit carry over & & & -32.182 & $(-2.83)^{* * *}$ \\
\hline Revenue limit & & & 1.844 & 0.07 \\
\hline Expenditure limit & & & 28.600 & 0.80 \\
\hline Constant & 67.04 & 6.12 & 37.53 & 1.34 \\
\hline$R^{2}$ & 0.77 & & 0.77 & \\
\hline No. of observations & \multicolumn{2}{|c|}{591} & \multicolumn{2}{|c|}{591} \\
\hline
\end{tabular}

Notes: Statistical significance levels are as follows: ${ }^{*} 0.10,{ }^{* *} 0.05$, and ${ }^{* * *} 0.01$.

Alaska is excluded as an extreme outlier and Wisconsin excluded due to missing observations.

Financial variables (in per capita terms) are adjusted using the BEA price index for state and local government expenditures.

Coefficients for state and year dummies are available on request from authors, but are not included in the table.

The coefficients of other state funds and federal funds also present a positive sign, which suggests that these two capital financing sources may also contribute to increasing the short-run cyclical variability of capital expenditures. Their magnitudes, however, are much smaller at only about 20 percent of the pay-go coefficient. Debt (bonds) stands out as the only financing source that may help reduce the short-run variability (negative 
sign), which is consistent to the findings of an earlier study. ${ }^{42}$ The size of it looks very small: each dollar of bonds may reduce the variability by only 17 cents, or $3 / 10$ ths of a percent; but since the state average of debt is about $\$ 72$ per capita, the cumulative effect can be as large as $\$ 23.6$, near half of total short-run fluctuations. Among the socioeconomic variables, unemployment rate and out-migration both pose positive results significant at the 5 or 1 percent level, respectively, suggesting that states with higher unemployment rates and out-migration ratios are more likely to experience higher cyclical variability in their capital outlays.

Similar to model 2, we test the effects of political and budgetary institutions on the short-run variability in model 4 . The estimated coefficients of the variables for the four capital financing sources are similar to those in model 3. "No deficit carryover" has a negative coefficient and is highly significant, which indicates that this budgetary rule has been effective in maintaining the short-run stability of state capital outlays. Other political and budgetary institutional variables do not seem to create a significant impact on the stability of capital expenditures.

\section{POLICY IMPLICATIONS AND CONCLUSION}

Pay-as-you-go (cash) financing of infrastructure poses multiple constraints; in contrast, pay-as-you-use (debt) presents many advantages by smoothing outlay over an extended period of time, thereby stabilizing tax rates and by improving intergenerational equity. For decades, debt has dominated the financing of capital outlay. It greatly boosted infrastructure construction; the use of municipal bonds has received significant academic attention. In recent years, however, there has been revived interest of the research community on pay-go as an alternate financing mechanism; but so far little is known about the use of pay-go financing. There has been inadequate study on the mechanisms and benefits of pay-go financing of state capital expenditures in the literature, and even less empirical research on the effects of pay-go financing on the cyclical patterns of state capital spending. This study is an attempt to fill in the niche. This paper has contributed to the literature by proposing a model that examines the effects of pay-go on the longrun volatility as well as the short-run cyclical variability of state capital expenditures. It has generated empirical evidence to suggest that the use of pay-go financing is associated with lower volatility in capital spending in the long run, but it contributes to increasing the cyclical variability of capital expenditures in the short run.

Although the results of this study seem a little detached from practice in a debtdominated world, they still bear (at least some) indirect implications for policy makers. Professional organizations such as GFOA and NASBO recommend pay-go as a best practice in public financial administration for more "rational" use of extra cash in boom years; such use of cash as a supplement to already dedicated debt financing of capital

42. McGranahan (1999). 
construction adds to the cyclical variability of capital outlay over the economic cycle. However, pay-go helps to maintain the long-run stability of state capital expenditures by reducing its volatility. The issuance of bonds could help reduce the short-run variability of capital spending, but it appears to contribute to increasing the volatility of capital spending in the long run. Therefore, we strongly recommend, based on the above results and inference, that states should consider more use of pay-go with less pay-use in boom years; the reserved debt capacity will then be released more intensively in lean years. In this way, pay-go will serve as a real complement to pay-use; the two mechanisms for financing infrastructure may work in unison to reduce the aggregate volatility and thereby improve the long-run stability of capital expenditures. That will be moving in the direction of the tax-smoothing approach and a symmetric counter-cyclical fiscal policy.

Finally, there is a caveat about this study. The results of this study are still very preliminary due to data limitations. More exhaustive research, with better, longer timeseries cross-sectional data, is necessary to improve our understanding of the mechanisms of capital financing in general and of the effects of pay-go on the stability of state capital expenditures in particular.

\section{NOTES}

The authors would like to acknowledge that the project was supported by the College Research Award of East Carolina University for spring 2008. 